January 2013

\title{
Crisis Informatics: Perspectives of Trust - Is Social Media a Mixed Blessing?
}

Christine Hagar

christine.hagar@sjsu.edu

Follow this and additional works at: https://scholarworks.sjsu.edu/ischoolsrj

Part of the Library and Information Science Commons

\section{Recommended Citation}

Hagar, C. (2013). Crisis Informatics: Perspectives of Trust - Is Social Media a Mixed Blessing?. School of Information Student Research Journal, 2(2). https://doi.org/10.31979/2575-2499.020202 Retrieved from https://scholarworks.sjsu.edu/ischoolsrj/vol2/iss2/2

This article is brought to you by the open access Journals at SJSU ScholarWorks. It has been accepted for inclusion in School of Information Student Research Journal by an authorized administrator of SJSU ScholarWorks. For more information, please contact scholarworks@sjsu.edu. 
Crisis Informatics: Perspectives of Trust - Is Social Media a Mixed Blessing?

\begin{abstract}
This paper highlights one of the key concerns in the emerging area of crisis informatics: issues of trusted information in crises/disasters and how the unregulated nature of social media affects information creation and dissemination. Deciding which information providers to trust and what sources of information to trust in crises is critical as acting upon trusted information can shape and influence the nature of the crisis. Social media is a powerful tool for sharing information during crises and can be used to improve emergency management capabilities, however, it has the power to misinform and to hinder response efforts.
\end{abstract}

\begin{abstract}
About Author
Dr. Christine Hagar is an Assistant Professor at San Jose State University, School of Library and Information Science. Dr. Hagar holds a PhD in Library and Information Science from the University of Illinois at Urbana-Champaign.
\end{abstract}




\section{Crisis Informatics: Perspectives of Trust - Is Social Media a Mixed Blessing?}

The world has experienced a number of devastating natural disasters and seems to be facing crises on an unprecedented scale. Natural disasters over the last decade, including major earthquakes in Haiti, New Zealand, Chile, China, and Japan (and the resultant tsunami/nuclear crisis), and more recently Hurricane Sandy, have claimed thousands of lives. As well as coping with such natural disasters, the world has faced other types of crises: political disruption in North Africa and the Middle East, human-made crises such as terrorist attacks (9/11, Mumbai bombings), the spread of viral disease (H1N1), nuclear and chemical crises (Bhupal, Chernobyl), war, and many more. This paper highlights one of the key concerns in the emerging area of crisis informatics: issues of trusted information in crises/disasters and how the unregulated nature of social media affects information creation and dissemination.

\section{Crisis informatics}

Crisis informatics is an interdisciplinary area of study. The term was first coined by Hagar (2006) and is broadly defined as the interconnectedness of people, organizations, information, and technology during crises. It examines the intersecting trajectories of social, technical, and information matters in crises/disasters and explores the full life cycle of a crisis: preparation, response, and recovery. Crises usually precipitate an increase in communication and present complex information environments. Within this complex information environment, trusted information takes on greater significance during a crisis.

\section{Trust}

Trust is a central component of everyday life and a high level of trust is key to effective communication (Dodgson, 1993). It can improve the quality of dialogue and discussions that facilitate the sharing of knowledge (Ichijo, von Krogh, \& Nonaka, 2000). Trust is at the heart of knowledge exchange (Davenport \& Prusak, 1998), enabling exchanges among individuals, enhancing cooperation and coordination, and contributing to more effective social and organizational relationships. However, during a crisis, the saliency of trust (and estimating trustworthiness) is elevated to higher levels (Webb, 1995).

Definitions of trust focus on the role of uncertainty in shaping people's experiences (Kollock, 1994). In a crisis situation when there is much uncertainty, trust influences the way people seek information. Bucher (2002) identifies knowledge uncertainty as a key element of crisis situations; those experiencing the crisis do not know enough to understand what is happening and lack knowledge about how to respond to the crisis.

Trust is an essential ingredient in social relationships (Brockner, Siegel, Daly, \& Tyler, 1997) because it defines an individual's expectations 
and behavior (Luhman, 1979). As dependency on other people in a crisis is greater (Webb, 1995), so social relationships become more important. McDowell (2002) argues that how much people trust other people or institutions affects the level of information they gain from them. Dependency on other people is often evident in crises when decisions are made about trustworthy sources of information and trustworthy people.

Two of the key questions explored are: What sources of information do people trust? Which information providers do people trust? The sources of information which are trusted are often influenced by existing relationships with the information provider. Deciding which sources of information to trust and which information providers to trust in crises are critical because acting upon trusted information can shape and influence the nature of the crisis profoundly. Lack of trust in crises/disasters leads to people making up stories, and rumors abound as elaborated below.

\section{Rumor}

Rumors tend to circulate rapidly and are underpinned by a desire for meaning to cope with uncertainties (Michelson \& Mouly, 2004). When people do not acquire the information they need to deal with a crisis, they seek information in rumor and to try to create a narrative that makes sense and fills the gaps in knowledge. As information is spread via rumor it becomes exaggerated and is difficult to ignore as people seek information and explanations.

During the 2009 HIN1 pandemic, rumors were rife and people sought information on: who was infected?; where did the H1N1 virus originate?; how quickly did the virus spread?; how was the virus passed on?; how many people would get it?; what precautions to take?; who would be given priority for vaccination?; and, questions concerning government involvement, such as was swine flu just a big rumour to jumpstart the people, to spend money on the health industry and boost the global economy? Important questions to explore are: How do we distinguish between rumor and information? And how do we decide how trustworthy the information content is? How much information in rumor is true and how is that worked out and by whom?

\section{Social media}

In years gone by, rumors circulated by word-of-mouth and were slow to spread. With the increased use of social media tools, rumors spread at a greater pace, creating a major challenge for crisis information management. Social media is an important platform to disseminate information locally and globally during crises. Tools such as Facebook, Twitter, Google Person Finder, Google Crisis Response, Youtube, and Flickr are changing the face of managing information in crisis preparedness, response, and recovery. These tools are used to send personal messages, retrieve local information to communities, find missing people, coordinate relief efforts, fundraise, organize volunteer groups, and to mobilize. Vast amounts of information can be distributed easily to a large audience at great speed. As crises unfold, social 
media enable events to be communicated around the world within minutes or even seconds of the crisis occurring. During the Haiti earthquake, social media became the new forum for collective intelligence, social convergence, and community activism (Keim \& Noji, 2011). Similarly much of what people around the world learned about the 2011 Japan earthquake during the hours and days after the event was significantly shaped by social media (Slater, Keiko, \& Kindstrand, 2012).

Social media enhances citizen engagement and allows citizens to become content generators and disseminators and to become "citizen journalists" to mobilize and spread their messages. During Hurricane Sandy, volumes of citizen-generated data was created using social media. Twitter registered 20 million Sandy-related tweets during the six-day period of the storm and the immediate aftermath. Facebook's Instagram reported that 10 photos per second related to Sandy were being uploaded to its site.

Besides vast amounts of citizen generated information disseminated via social media, relief agencies, such as the Red Cross, and local, state, and federal emergency management organizations, are increasingly using social media as an alternative way to communicate with the public, and with each other (White, 2012). Official and unofficial sources of information are present and shared on the same social platforms. During Hurricane Sandy, for example, information was posted on Twitter by city departments, by public transit authorities, by news organizations, and by citizens conveying information about the state of their neighbourhoods, and exchanging information about the safety of family and friends.

The combination of a vast amount of official sources of information, and the citizen-generated content created and disseminated via social media, adds to information overload in crises. This increases uncertainty and the difficulty of making decisions about whom and what are trustworthy sources of information. When formal channels of information do not answer questions, informal channels fill the gap. In a crisis, informal channels of information become even more important as people seek information from people who they know and trust. One of the challenges for centralized authorities and for the emergency management community is how to coordinate and aggregate the unofficial citizen generated content into their official sites, and what to include. Crisis responders need to be able to filter and process volumes of crisis data and navigate through the "noise" on social media sites (Starbird et al., 2012).

Not only have social media tools the capacity and power to inform, to provide real-time information, facilitate recovery efforts, and save lives, but they also have the potential to spread misinformation and rumor, and to create panic. During Hurricane Sandy, rumors and fake images of the storm were virally shared, including a picture of a shark swimming in a front yard in Brigantine, New Jersey and a rumor claiming that the floor of the New York Stock exchange was three feet under water. "Retweets" allowed the further 
spread of these rumors. In response to the multitude of rumors FEMA set up a "rumor control" section on its website (FEMA, 2012).

Deciding which information providers to trust and what sources of information to trust in crises is critical as acting upon trusted information can shape and influence the nature of the crisis. Social media is a powerful tool for sharing information during crises and can be used to improve emergency management capabilities. Some would argue that the promise of positive results merit further use of social media for emergencies and disasters (Lindsay, 2011), however, on the other hand, social media has the power to misinform and to hinder response efforts. Is it a mixed blessing in crisis response?

\section{References}

Brockner, J., Siegel, P. A., Daly, J. P., \& Tyler, T. (1997). When trust matters: The moderating effects of outcome favourability. Administrative Science Quarterly, 43, 558-583.

Bucher, H-J. (2002). Crisis communication and the internet: Risk and trust in a global media, First Monday, 7, 4. Retrieved from http://firstmonday.org/issues/issue7 4/bucher/index.html

Davenport, T. H., \& Prusak, L. (1998). Working knowledge: How organizations manage what they know. Cambridge, MA: Harvard Business School Press, 1998.

Dodgson, D. (1993). Learning, trust and technological collaboration. Human Relations, 46, 77-95.

FEMA. (2012). Rumor control. Retrieved from https://twitter.com/fema/status/265605032311930880

Hagar, C. (2006). Using research to aid the design of a crisis information management course. Paper presented at ALISE Annual Conference SIG Multicultural, Ethnic \& Humanistic Concerns (MEH). Information Seeking and Service Delivery for Communities in Disaster/ Crisis, San Antonio.

Ichijo, K., von Krogh, G., \& Nonaka, I. (2000). Knowledge enablers. In G. von Krogh, J. Roos, \& D. Kleine (Eds.) Knowing in firms: Understanding, managing and measuring knowledge (pp. 173-230). London: Sage. 
Keim, M. E., \& Noji, E. (2011). Emergent use of social media: A new age of opportunity for disaster resilience. American Journal of Disaster Medicine, 6(1), 47-54.

Kollock, P. (1994). The emergence of exchange structures: An experimental study of uncertainty, commitment and trust. American Journal of Sociology, 100(2), 313-345.

Lindsay, B. R. (2011). Social media and disasters: Current uses, future options, and policy considerations. Congressional Research Service Report for Congress. Retrieved from http://www.fas.org/sgp/crs/homesec/R41987.pdf

Luhmann, N. (1979). Trust and power. Chichester, UK: John Wiley \& Sons.

McDowell, A. (2002). Trust and information: The role of trust in the social epistemology of information science. Social Epistemology, 16, 51-63.

Michelson, G., \& Mouly, V. S. (2004). Do loose lips sink ships?: The meaning, antecedents and consequences of rumour and gossip in organisations. Corporate Communication, 9(3), 189-201.

Slater, D. H., Keiko, N., \& Kindstrand, L. (2011). Social media in disaster Japan. In Kingston (Ed.) Natural disaster and nuclear crisis in Japan (pp. 94-108). Oxford, UK: Routledge.

Starbird, K., Palen, L., Liu, S. B., Vieweg, S., Hughes, A., Schram, A., . . \& \& Schenk, C. (2012). Promoting structured data in citizen communications during disaster response: An account of strategies for diffusion of the 'Tweak the Tweet' syntax. In C. Hagar (Ed.) Crisis information management: Communication and technologies (pp. 4362). Oxford, UK: Chandos Publishing.

Webb, E. J. (1995). Trust and crisis. In R. Kramer \& T. R. Tyler (Eds.) Trust in organizations. London: Sage. 